\title{
Changes in innate immune response and detoxification in Melipona quadrifasciata (Apinae: Meliponini) on oral exposure to azadirachtin and spinosad
}

\author{
Thaís Andrade Viana ${ }^{1}$, Wagner Faria Barbosa ${ }^{1}$, Anete Pedro Lourenço ${ }^{2}$, \\ Weyder Cristiano Santana ${ }^{1}$, Lúcio Oliveira CAMPOS $^{3}$, Gustavo Ferreira Martins ${ }^{3}$ \\ ${ }^{1}$ Departamento de Entomologia, Universidade Federal de Viçosa, Viçosa, MG 36570-900, Brazil \\ ${ }^{2}$ Departamento de Ciências Biológicas, Universidade Federal dos Vales do Jequitinhonha e Mucuri, Diamantina, MG \\ 39100-000, Brazil \\ ${ }^{3}$ Departamento de Biologia Geral, Universidade Federal de Viçosa, Viçosa, MG 36570-900, Brazil
}

Received 19 February 2020 - Revised 17 July 2020 - Accepted 29 September 2020

\begin{abstract}
Exposure to agrochemicals and pathogens has been indicated as critical factors of declining pollinator populations, including species of native tropical bees. In the present study, we investigated the sublethal effects of acute oral exposure to azadirachtin and spinosad bioinsecticides on the expression of immunity-related genes and the number of hemocytes in uninfected and Escherichia coli-infected workers of the stingless bee Melipona quadrifasciata. Expression of the immune-related gene vitellogenin decreased and the number of circulating hemocytes increased in bioinsecticide-exposed uninfected bees and in unexposed $E$. coli-infected bees as compared with unexposed uninfected bees. Our results show that though bioinsecticides are considered safe, contamination by sublethal doses of azadirachtin and spinosad can interfere with the immune system of bees.
\end{abstract}

\section{bioinsecticides / hemocytes / spinosad / stingless bees / vitellogenin}

\section{INTRODUCTION}

Control of insects using insecticides is a critical process in agriculture. Different types of insecticides have been used for pest control, with bioinsecticides (i.e., insecticides from natural origin) being an important group (Gullan and Cranston 2012). This is because the use of bioinsecticides is considered to mitigate environmental impacts, including risk to

Supplementary Information The online version of this article (https://doi.org/10.1007/s13592-020-00814-w) contains supplementary material, which is available to authorized users.

Corresponding author: G. Martins, gmartins@ufv.br Manuscript editor: Michelle L Flenniken pollinators, due to their natural origin (Barbosa et al. 2015a; Lima et al. 2016).

Insecticides cause diverse sublethal effects to insects (Desneux et al. 2007), and irrespective of their origin, their usage may lead to a decline in pollinator populations (Potts et al. 2010). Pollinators can be affected by (bio) insecticides via contact with contaminated surfaces of plants (Koch and Weisser 1997) or ingestion when collecting contaminated food (Guedes et al. 2016). Forager bees, for instance, can take contaminated supplies to their colonies, where they distribute them through trophallaxis or larval feeding (Rortais et al. 2005; Krupke et al. 2012; Lima et al. 2016).

Stingless bees (Meliponini) are pollinators under high risk of exposure to pesticides since they comprise a broad group of bee species in the neotropics (Silveira et al. 2002; Michener 
2013) - a region with intense and extensive use of agrochemicals for crop protection (Barbosa et al. 2015b; Lima et al. 2016). Melipona is a eusocial genus with the most significant number of species, including Melipona quadrifasciata, within the Meliponini tribe (Silveira et al. 2002; Michener 2013). This species is considered an important pollinator of Neotropical ecosystems, as they also perform buzz pollination (Slaa et al. 2006; Dos Santos et al. 2009). They pollinate cultivable plants such as tomatoes (Del Sarto et al. 2005), peppers (Cruz et al. 2005), and eggplants (Nunes-Silva et al. 2013). In Brazil, agrochemicals such as the bioinsecticides azadirachtin and spinosad are commonly used in these crops (ANVISA 2018).

Insect immune system comprises both cellular and humoral response (Strand 2008). The cellular response is mediated by hemocyte activity that can result in phagocytosis, nodule formation, and encapsulation (Amaral et al. 2010; Ravaiano et al. 2018a). The humoral response is mainly elicited by soluble compounds such as antimicrobial peptides (AMPs), which includes apidaecin, hymenoptaecin, abaecin, and defensin (Evans et al. 2006; Lourenço et al. 2009, 2013; Christen et al. 2016; Hu et al. 2017). In bees, intoxication by insecticides affects both cellular and humoral responses, causing variation in hemocyte populations (Brandt et al. 2017; Ravaiano et al. 2018b), reduction in encapsulation response (Abbo et al. 2017), and modification in the synthesis of AMPs (Di Prisco et al. 2013; Christen et al. 2016; Garrido et al. 2016).

The vitellogenin $(\mathrm{Vg})$ protein is also involved in the immunity of bees besides multiple other processes such as reproduction, oxidative stress resistance, nutrient storage, hormonal dynamics, diet-related behavior, and ageing (Amdam et al. 2005, 2006; Seehuus et al. 2006; Dallacqua et al. 2007). Vg also plays a role in vertical immunity (from mother to offspring) (Salmela et al. 2015) and changes in its expression may serve as a parameter to measure energy stress levels and sublethal effects of insecticides (Christen et al. 2016; Abbo et al. 2017). Another form of insect defense is the detoxification system that contributes to the maintenance of homeostasis. Detoxification is carried out by enzymes (e.g., superoxide dismutase or SOD) that metabolize xenobiotics, including pesticides (Derecka et al. 2013; Christen et al. 2016; Chaimanee et al. 2016).

The majority of the studies on the effects of insecticides on pollinator immunity have focused on species of the genera Apis and Bombus (Lima et al. 2016), whereas other diverse genera, including the genus Melipona (Barbosa et al. 2015a, b; Tomé et al. 2012, 2015; Lima et al. 2016; Ravaiano et al. 2018b), are less studied. Therefore, studies on the immune stress of stingless bees exposed to insecticides and/or pathogens are critical to understanding the role of these stressors in the mortality of bees. This study aimed to understand the effects of acute oral exposure of azadirachtin (neem) and spinosad bioinsecticides on the innate immune response and detoxification process of newly emerged $M$. quadrifasciata workers by gene expression analysis (real-time qPCR) and total hemocyte count (THC) after infection with Escherichia coli.

\section{MATERIALS AND METHODS}

\subsection{Bees}

Bees of the species M. quadrifasciata were collected from three managed colonies present in the Central Apiary of Universidade Federal de Viçosa - UFV, Viçosa, Minas Gerais $\left(20^{\circ} 45^{\prime}\right.$ $14^{\prime \prime} \mathrm{S}$ and $\left.42^{\circ} 52^{\prime} 55^{\prime \prime} \mathrm{W}\right)$. Brood combs containing dark-eyed pupae (approximately 20 days of pupation) were collected from natural colonies, placed in Petri dishes, and stored in an incubator at $28{ }^{\circ} \mathrm{C}$ and $70 \%$ relative humidity $(\mathrm{RH})$ under complete darkness (Teles et al. 2007; Borges et al. 2012; Tomé et al. 2012). The brood cells were uncapped with tweezers to enable adult emergence. The newly emerged workers $(\leq 24 \mathrm{~h})$ were kept in the incubator for 3 days after emergence and fed ad libitum with $50 \%$ solution of Apis mellifera honey and pollen collected from natural colonies of $M$. quadrifasciata (Borges et al. 2012).

\subsection{Bioinsecticide exposure}

Commercial formulations of azadirachtin (Cursor, $10 \mathrm{~g} \mathrm{Kg}^{-1}$, Biocard Indústria Química LTDA, 
Curitiba, PR, Brazil) and spinosad (Tracer, $480 \mathrm{~g} \mathrm{~L}^{-1}$, Dow AgroScience, Santo Amaro, SP, Brazil) were diluted in $50 \%$ solution of honey and distilled water $(\mathrm{v} / \mathrm{v})$ to obtain doses of 6.00 and $5.29 \mathrm{ng}$ active ingredient (a.i)./bee, respectively (Botina et al. 2020). The highest dose that did not cause lethargy in bees was chosen for azadirachtin, based on pre-tests. The spinosad dose was chosen based on the $\mathrm{LD}_{5}$ (dose needed to kill 5\% of individuals) value for M. quadrifasciata (Tomé et al. 2015).

Exposure to bioinsecticides was carried out by feeding the bees $2 \mu \mathrm{L}$ of contaminated or uncontaminated (control) diets after $18 \mathrm{~h}$ of fasting to stimulate food ingestion (Tomé et al. 2015; Ravaiano et al. 2018b; Botina et al. 2020). The starving period was essential as young emerged workers have deficient energy requirements and feed on insufficient amounts of honey under laboratory conditions. Four-day-old bees were individually transferred to parafilm-sealed cylindrical glasses (Parafilm M, PPP Co., Chicago, IL, USA) for 15 min until feeding (Tomé et al. 2015). Subsequently, the bees were incubated for $24 \mathrm{~h}$ and fed ad libitum with a $50 \%$ solution of honey and fermented pollen. This period of incubation was sufficient to change the gene expression and hemocyte abundance (Chaimanee et al. 2016; Christen et al. 2016; Ravaiano et al. 2018b).

\subsection{Assay for gene expression analysis}

Five individuals for each bioinsecticide (azadirachtin and spinosad) and control were used per colony. They were individually analyzed for possible genetic differences as they were halfsisters.

\subsection{RNA extraction and cDNA synthesis}

For total RNA extraction, only the bee's abdomen was used as it contains a substantial amount of fat body and hemolymph, where gene expression (GenBank accession number in Supplementary Table 1) is considered to be high due to multiple metabolic functions (Arrese and Soulages 2010). The abdomen of each bee was stored in $500 \mu \mathrm{L}$ of Trizol (Invitrogen) at $-80{ }^{\circ} \mathrm{C}$ for isolation of total
RNA. RNA extraction was performed according to the Trizol manufacturer's instructions. RNA samples were treated with DNase (deoxyribonuclease I, Invitrogen) to remove genomic DNA.

The quantity of RNA was estimated at $260 \mathrm{~nm}$ using a NanoDrop spectrophotometer (Thermo Scientific) while protein and/or phenol contamination was detected by calculating the 260/280 ratio. Reverse transcription for cDNA synthesis was performed using $1 \mu \mathrm{g}$ total RNA, $1 \mu \mathrm{L}$ reverse transcriptase (NextGeneration MMLV RNAse H Minus-Strand First Generation cDNA Synthesis Kit, DNA express), and Oligo (dT) 20 primer (Invitrogen) or ReadyMade ${ }^{\text {TM }}$ Primer Oligo IDT, 20 units $(10 \mu \mathrm{g})$ in the presence of RNase inhibitors (RNaseOUT ${ }^{\mathrm{TM}}$, Invitrogen) in a final volume of $20 \mu \mathrm{L}$; all the steps were carried out as per the manufacturer's guidelines.

\subsection{Real-time PCR}

Real-time PCR was performed in triplicate. Amplification reactions were performed using $5 \mu \mathrm{L}$ of EvaGreen qPCR LOW ROX Reaction Buffer, $0.2 \mu \mathrm{L}$ of HotStart Taq DNA Polymerase (Next Generation ECO EvaGreen HotStart qPCR LOW ROX Kit, DNA express), and $1 \mu \mathrm{L}$ of $5 \times$ diluted cDNA and primers. The concentration of primer was $150 \mathrm{nM}$ for $r p L 32$ and abaecin, and $200 \mathrm{nM}$ for $S O D$ and $V g$ (Supplementary Table 1), supplemented with ultrapure water to obtain a final volume of $10 \mu \mathrm{L}$. The reaction conditions were $95{ }^{\circ} \mathrm{C}$ for $10 \mathrm{~min}$, and 40 cycles of $95^{\circ} \mathrm{C}$ for $15 \mathrm{~s}$, and $60{ }^{\circ} \mathrm{C}$ for $1 \mathrm{~min}$, followed by a melting curve of $95^{\circ} \mathrm{C}$ for $15 \mathrm{~s}$ and $55^{\circ} \mathrm{C}$ for $1 \mathrm{~min}$ and finally $95^{\circ} \mathrm{C}$ for $15 \mathrm{~s}$. Primer specificity was analyzed using the melting curve. Primers for M. quadrifasciata were designed using Primer3 software version 0.4.0 (http://bioinfo. ut.ee/primer3-0.4.0/) with sequences deposited in GenBank (Supplementary Table 1) except for the reference gene. The reference gene was $r p L 32$, whose primer sequences are for A. mellifera, but worked very well on $M$. quadrifasciata. They were designed from a suitable reference gene for qPCR analyses in honey bees (Lourenço et al. 2008) and were already used in qPCR experiments in $M$. quadrifasciata (Borges et al. 2012). Amplification efficiency (Supplementary Table 1) was tested for each primer pair (Bustin et al. 2009). 


\subsection{Relative quantification of transcripts}

The relative quantification of target gene transcripts was performed by calculating the difference between the $\mathrm{Ct}$ values (threshold PCR cycle) of each technical triplicate and the $\mathrm{Ct}$ values of each triplicate of the reference gene $r p L 32$, according to the instructions of the User Bulletin \#2 (Applied Biosystems). First, the Ct averages of the three technical readings of each sample were estimated for both the target gene and the reference gene. For each sample, the $\mathrm{Ct}^{\text {targetgene }}$ mean value was subtracted from the $\mathrm{Ct}^{\text {referencegene }}$, giving the $\Delta \mathrm{Ct}$. Subsequently, a $\Delta \mathrm{Ct}$ corresponding to a calibrator was chosen (a control sample was chosen) and all values were normalized by subtracting the chosen $\Delta \mathrm{Ct}$. Thus, the $\Delta \Delta \mathrm{Ct}$ was obtained. The final relative quantification value was given by $2^{-\Delta \Delta \mathrm{Ct}}$, where the calibrator is equal to one.

\subsection{Bacterial and insecticide test}

Escherichia coli K-12, supplied by the Laboratório de Genética Molecular de Bactérias - UFV, was used to challenge the immune system of M. quadrifasciata . Escherichia coli $\left(1.3 \times 10^{7}\right.$ colony forming units $\mathrm{CFU} / \mathrm{ml}$ ) was cultured on BD Brain Heart Infusion Agar (BHI Agar, Becton Dickinson Company, Heidelberg, Germany) and stored at $-80{ }^{\circ} \mathrm{C}$ until injection into the bees. After $24 \mathrm{~h}$ of feeding with contaminated or uncontaminated diet (item 2.2), bees were injected with $10 \mu \mathrm{L}$ of sterilized BHI medium (control) or BHI containing E. coli (BD Ultra-Fine, 0.25-mm gauge needle, Uniqmed, São Paulo, SP, Brazil) in the first abdominal tergite of cold-anesthetized bees at $4{ }^{\circ} \mathrm{C}$, using an insulin syringe. Hemolymph was collected and analyzed for THC $1 \mathrm{~h}$ post-injection (Ravaiano et al. 2018a, b).

The experiment was carried out in a factorial scheme determined by exposure to bioinsecticides (factor A) and inoculation with bacteria (factor B). Six treatments were established considering the combinations between 3 levels of factor A and 2 levels of factor B: (1) workers treated with spinosad and sterilized BHI medium; (2) workers treated with azadirachtin and sterilized BHI medium; (3) workers treated with uncontaminated food and sterilized BHI medium; (4) workers treated with uncontaminated food and bacteria; (5) workers treated with spinosad and bacteria, and (6) workers treated with azadirachtin and bacteria. Three individuals were used per colony for each treatment, for a total of nine individuals used per treatment.

\subsection{Hemolymph collection and total hemocyte count}

To collect hemolymph, $20 \mu \mathrm{L}$ of anticoagulant solution $(0.098 \mathrm{M} \mathrm{NaOH}, 0.145 \mathrm{M} \mathrm{NaCl}$, $0.017 \mathrm{M}$ EDTA, and $0.041 \mathrm{M}$ citric acid, $\mathrm{pH}$ 4.5) was injected into the first abdominal tergite of anesthetized bees using an insulin syringe (Araújo et al. 2008). Then, a slight pressure was applied to the bee's abdomen to expel a hemolymph droplet through the hole created by the needle. Micropipettes with siliconized tips of SigmaCote (Sigma) were used to collect hemolymph for THC. From each bee, $10 \mu \mathrm{L}$ of hemolymph was collected and dispensed directly (undiluted) in an improved Neubauer chamber and counted under a Primo Star Zeiss trinocular microscope with a magnification of $\times 400$ (Ravaiano et al. 2018a, b).

\subsection{Statistical analysis}

Real-time PCR quantification results for each gene were grouped according to treatment and subjected to statistical analysis. $V g$ expression data were analyzed using a generalized linear model based on Gamma distribution of residues (Crawley 2012) (no transformation was able to normalize the distribution of residuals) and the treatments were subjected to the $\chi^{2}$ test $(p=$ 0.05) (PROC GENMOD; SAS Institute 2008). THC was analyzed considering the $2 \times 3$ factorial scheme (factor A: bacterial infection (without and with infection); factor B: exposure to bioinsecticides (control, azadirachtin, and spinosad)). Abaecin expression, SOD, and THC data were logarithmized $\left(\log _{10}\right)$ and analyzed using a general linear model based on the Gaussian distribution of residues and the treatments were subjected to the $F$ test $(p=0.05)$ (PROC GLM; SAS Institute 2008), subsequently, Tukey's test was performed ( $p=0.05$ ). 


\section{RESULTS AND DISCUSSION}

\subsection{Gene expression}

Acute oral exposure to azadirachtin or spinosad did not change the expression of abaecin in M. quadrifasciata workers $\left(F_{2,40}=0.04 ; p=0.96\right)$ (Figure 1a) under the conditions tested in the current study. This is consistent with the reports of previous studies that abaecin expression in A. mellifera adults was not affected by exposure to coumaphos (an acaricide), tau-fluvalinate (a pyrethroid), imidacloprid (a neonicotinoid), and spinosad (Garrido et al. 2016; Collison et al. 2018; Christen et al. 2019). However, the effects of pesticides on abaecin expression seem to depend on the dose, concentration, or mode of action of the pesticide, and the species exposed. For example, it has been reported that abaecin expression in A. mellifera adults decreased on exposure to the neonicotinoid thiamethoxam (Collison et al. 2018) but increased in Bombus impatiens on exposure to imidacloprid (Simmons and Angelini 2017). In addition, abaecin expression increased in A. mellifera adults after treatment with the fungicide prochloraz (Glavinic et al. 2019), and in its larvae after treatment with the herbicide glyphosate (Vázquez et al. 2018).

Similar to abaecin, exposure of M. quadrifasciata to azadirachtin or spinosad did not alter the relative expression of $S O D \quad\left(F_{2.40}=0.78 ; p=0.463\right)$ (Figure 1b). Changes in $S O D$ expression may also be dependent on factors such as active ingredient, dose and exposure time of the pesticide, and the bee species (Garrido et al. 2016; Simmons and Angelini 2017; Collison et al. 2018; Christen et al. 2019). For example, in newly emerged A. mellifera, $S O D$ expression levels decreased in workers but increased in queens when they were exposed to low concentrations of imidacloprid or coumaphos (Chaimanee et al. 2016).

Unlike abaecin and $S O D$, exposure of M. quadrifasciata to azadirachtin or spinosad changed $V g$ expression $\left(\chi^{2}=9.81 ; \mathrm{df}=2 ; p=\right.$ 0.007). $V g$ expression was lower after exposure to azadirachtin $\left(\chi^{2}=3.89 ; \mathrm{df}=1 ; p=0.0486\right)$ and spinosad $\left(\chi^{2}=5.85 ; \mathrm{df}=1 ; p=0.015\right)$ than in the control (Figure 1c). Decreased Vg levels were also reported in newly emerged/naïve A. mellifera exposed to pesticides of different spectra, including coumaphos, tau-fluvalinate, and imidacloprid (Chaimanee et al. 2016; Abbo et al. 2017); this decrease can be related to energy reallocation (tradeoff) between reproduction and immune stimulation (Rolff and Siva-Jothy 2002; Lourenço et al. 2009).

\subsection{Total hemocyte count}

The cellular immune response can be measured based on the number of circulating hemocytes after challenging (Brandt et al. 2016, 2017; Quintana et al. 2019). Therefore, we measured the THC in M. quadrifasciata after exposure to azadirachtin and spinosad in uninfected bees and bees infected with $E$. coli. A significant link between exposure to bioinsecticides and bacterial infection was detected for THC $\left(F_{2.46}=5.29 ; p=0.009\right)$. Infected bees that fed on the uncontaminated diet (i.e., without insecticides) had a higher amount of hemocytes than uninfected bees that fed on uncontaminated diet $(p=$ 0.001) (Figure 2). However, no significant changes
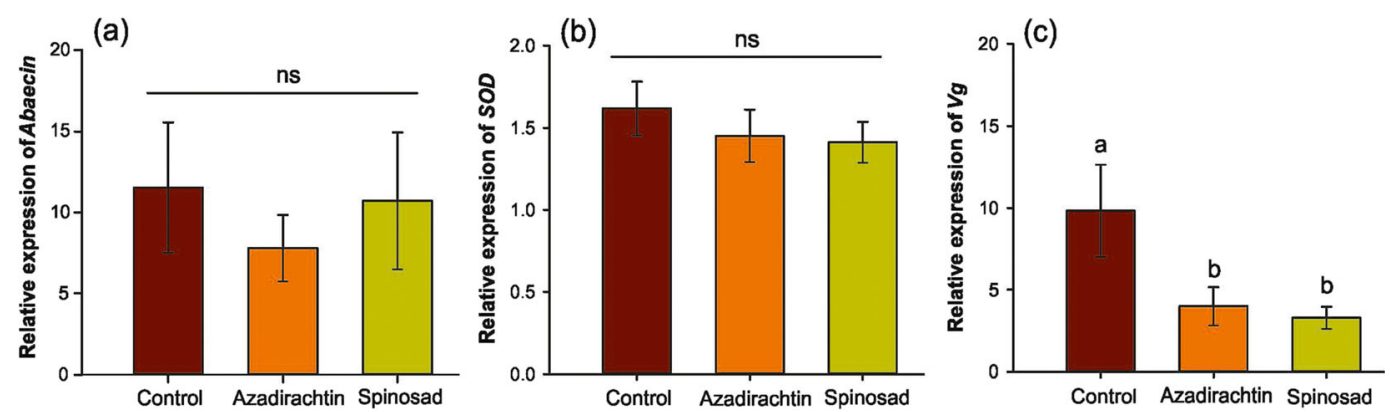

Figure 1. Relative expressions of abaecin (a), superoxide dismutase (SOD) (b), and vitellogenin $(\mathrm{Vg})(\mathbf{c})$ in Melipona quadrifasciata adult workers orally exposed to azadirachtin and spinosad. Different letters indicate significant differences by the $\chi^{2}$ test $(p<0.05)$ in c. "ns" indicates not significant by the $F$ test $(p>0.05)$ in a and $\mathbf{b}$. 
in THC were detected between infected and uninfected bees exposed to azadirachtin $(p=0.903)$ or $\operatorname{spinosad}(p=1.000)$. It is noteworthy that an increase in THC occurs in individuals fed with uncontaminated diet after bacterial infection, and this increase seems to be due to the increase in the number of granulocytes upon infection (Ravaiano et al. 2018b).

Among infected bees, individuals exposed to azadirachtin had higher THC than those fed with uncontaminated diet $(p=0.003)$ (Figure 2). The reason for this could be the proliferation and differentiation of hemocytes due to insecticide exposure (Disale et al. 2013; Perveen and Ahmad 2017; Ravaiano et al. 2018b). However, THC was not different between bees fed with uncontaminated diet and bees exposed to spinosad $(p=1.000)$. In the case of uninfected individuals, oral exposure to azadirachtin and spinosad led to an increase in THC as compared with unexposed individuals (Figure 2). Similarly, an increase in THC was reported in Popillia japonica adults (Coleoptera) exposed to Monodhan 36 (organophosphate) and Sevin (carbamate) (Disale et al. 2013). In contrast, adults of $A$. mellifera showed a reduction in THC (Brandt et al. 2016, 2017) while M. quadrifasciata showed stable THC (Ravaiano et al. 2018b) on exposure to neonicotinoids, suggesting that the effect on THC depends on the insecticide's mode of action or species exposed.
Azadirachtin acts by inhibiting the release of the prothoracicotropic hormone, which influences the release of ecdysteroids and, thereby, prevents molting (Gullan and Cranston 2012). Chronic exposure of $M$. quadrifasciata larvae to azadirachtin also reduced the survival and body mass of larvae as well as increased the production of deformed individuals (Barbosa et al. 2015b). Azadirachtin also impaired flight activity in M. quadrifasciata (Tomé et al. 2015). Spinosad acts by opening of ion channels of the postsynaptic membrane, acting as an agonist to the neurotransmitter acetylcholine. Besides this, spinosad also acts on GABA (gammaamino acid) receptors (Salgado 1998) and may inhibit acetylcholinesterase, leading to hyperexcitability in insects (Nathan et al. 2008). In addition to the effects described above, the present work has shown that both azadirachtin and spinosad interfere with THC and expression of $V g$ in M. quadrifasciata.

The current work is a pioneering study regarding the impacts of bioinsecticides on M. quadrifasciata, being the first to raise questions about the expression of genes related to the immunity of these bees, as well as to evaluate the hemocyte dynamics on exposure to bioinsecticides and pathogens. Although bioinsecticides are considered less detrimental to the environment and pollinators, the damage is caused to the immune system of stingless bees due to azadirachtin and spinosad poisoning, at least in

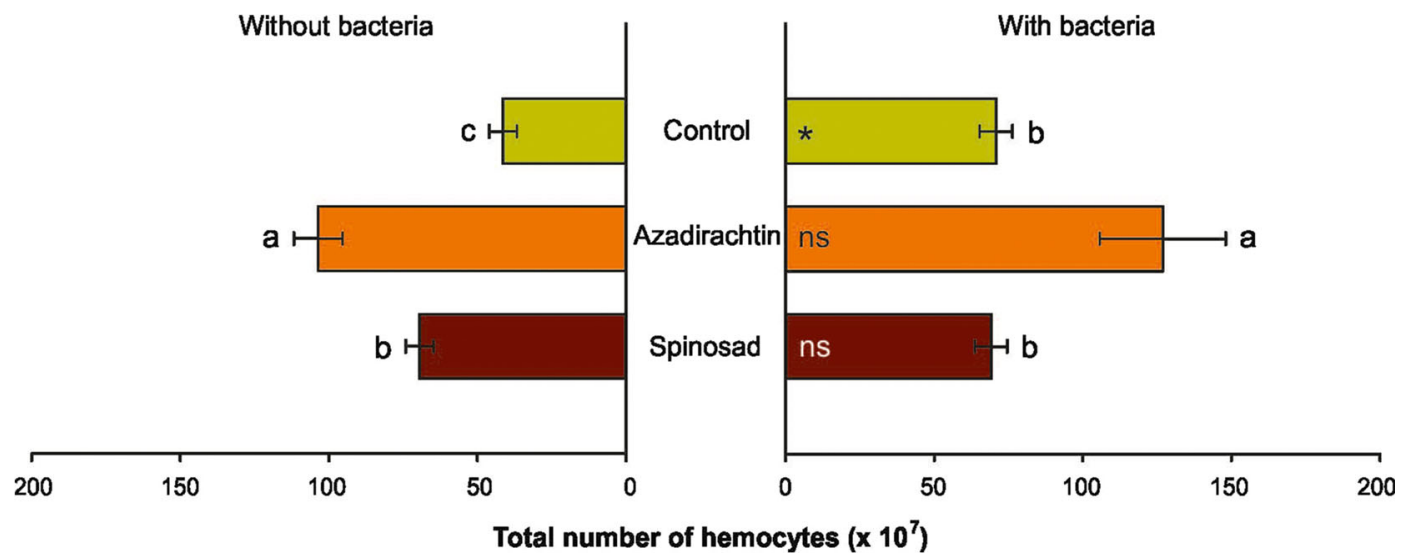

Figure 2. Total hemocyte count in Melipona quadrifasciata workers orally exposed to azadirachtin and spinosad and/or infected with the bacteria Escherichia coli. Different letters indicate a significant difference between the levels of insecticidal exposure (control, azadirachtin, and spinosad) within each level of infection (with sterilized BHI Agar or with bacteria) by Tukey's test $(p<0.05)$. The asterisk indicates a significant difference between infection levels (with sterilized BHI Agar or with bacteria) within each level of insecticidal exposure (control, azadirachtin or spinosad) by Tukey's test $(p<0.05)$. 
controlled conditions. Therefore, bioinsecticides should not be exempted from risk assessment analysis as they are hazardous even at sublethal doses. This study suggests that a greater focus on insecticide trials should be extended to other species for generating information to support conservation strategies for native pollinators. We also emphasize the need for field ecotoxicological studies to better understand the role of pesticides in the decline of the bee population.

\section{ACKNOWLEDGMENTS}

The authors thank the Conselho Nacional de Desenvolvimento Científico e Tecnológico (CNPq, 301725/2019-5) and Fundação de Amparo à Pesquisa do Estado de Minas Gerais (FAPEMIG, CBB-APQ-00247-14 and PPM-00225-16) for financial support provided.

\section{CODE AVAILABILITY}

Not applicable.

\section{AUTHORS' CONTRIBUTIONS}

TAV, WFB, APL, and GFM conceived this research and designed experiments. WCS and LAOC provided the bees and participated in the interpretation of the data. TAV and WFB performed the bench experiments and the statistical analyses. TAV, WFB, and GFM wrote the paper. TAV, WFB, APL, WCS, and GFM corrected the paper. All authors read and approved the final manuscript.

\section{FUNDING}

This study was funded by the Coordenação de Aperfeiçoamento de Pessoal de Nível Superior Brasil (CAPES) - Finance Code 001, Conselho Nacional de Desenvolvimento Científico e Tecnológico (CNPq, 301725/2019-5) and Fundação de Amparo à Pesquisa do Estado de Minas Gerais (FAPEMIG, CBB-APQ-00247-14, and PPM-00225-16).

\section{DATA AVAILABILITY}

Not applicable.

\section{COMPLIANCE WITH ETHICAL STANDARDS}

Conflict of interest The authors declare that they have no conflict of interest.

Ethics approval Not applicable.

Consent to participate Not applicable.

Consent for publication Not applicable.

\begin{abstract}
Modifications de la réponse immunitaire innée et détoxification chez Melipona quadrifasciata (Apinae : Meliponini) lors d'une exposition orale à l'azadirachtine et au spinosad.
\end{abstract}

Bioinsecticides / hémocytes / spinosad / abeilles sans dard / vitellogénine.

Veränderungen in der angeborenen Immunantwort und der Entgiftungsreaktionen bei Melipona quadrifasciata (Apinae: Meliponini) nach oraler Verabreichung von Azadirachtin und Spinosad.

Bioinsektizide / Hämozyten / Spinosad / Stachellose Bienen / Vitellogenin.

\section{REFERENCES}

Abbo, P.M., Kawasaki, J.K., Hamilton, M., Cook, S.C., DeGrandi-Hoffman, G., Li, W.F., Liu, J., Chen, Y.P. (2017) Effects of Imidacloprid and Varroa destructor on survival and health of European honey bees, Apis mellifera. Insect Sci., https://doi.org/10.1111/17447917.12335

Amaral, I.M.R., Neto, J.F.M., Pereira, G.B., Franco, M.B., Beletti, M.E., Kerr, W.E., Bonetti, A.M., Ueira-Vieira, C. (2010) Circulating hemocytes from larvae of Melipona scutellaris (Hymenoptera, Apidae, Meliponini): Cell types and their role in phagocytosis. Micron, https://doi.org/10.1016/j.micron.2009.10.003 
Amdam, G.V., Aase, A.L.T.O., Seehuus, S.C., Kim Fondrk, M., Norberg, K., Hartfelder, K. (2005) Social reversal of immunosenescence in honey bee workers. Exp. Gerontol., https://doi.org/10.1016/j. exger.2005.08.004

Amdam, G.V., Csondes, A., Fondrk, M.K., Page, R.E. (2006) Complex social behaviour derived from maternal reproductive traits. Nature, https://doi.org/10.1038 /nature 04340

ANVISA - Agência Nacional de Vigilância Sanitária (2018) Monografias autorizadas. http://portal.anvisa. g o v. b r/r e g i s t r o s - e autorizacoes/agrotoxicos/produtos/monografia-deagrotoxicos/autorizadas (Accessed 09.07.2020)

Araújo, H.C.R., Cavalcanti, M.G.S., Santos, S.S., Alves, L.C., Brayner, F.A. (2008) Hemocytes ultrastructure of Aedes aegypti (Diptera: Culicidae). Micron, https://doi.org/10.1016/j.micron.2007.01.003

Arrese, E.L., Soulages, J.L. (2010) Insect fat body: energy, metabolism, and regulation. Annu. Rev. Entomol., https://doi.org/10.1146/annurev-ento-112408-085356

Barbosa, W.F., Smagghe, G., Guedes, R.N.C. (2015a) Pesticides and reduced-risk insecticides, native bees and pantropical stingless bees: pitfalls and perspectives. Pest Manag Sci, https://doi.org/10.1002/ps.4025

Barbosa, W.F., Tomé, H.V.V., Bernardes, R.C., Siqueira, M.A.L., Smagghe, G., Guedes, R.N.C. (2015b) Biopesticide-induced behavioral and morphological alterations in the stingless bee Melipona quadrifasciata. Environ. Toxicol. Chem., https://doi. org/10.1002/etc.3053

Borges, A.A., Humann, F.C., Tavares, M.G., Campos, L.A.O., Hartfelder, K. (2012) Gene copy number and differential gene expression in haploid and diploid males of the stingless bee, Melipona quadrifasciata. Insectes Soc., https://doi.org/10.1007/s00040-0120259-1

Botina, L. L., Bernardes, R. C., Barbosa, W. F., Lima, M. A. P., Guedes, R. N., \& Martins, G. F. (2020). Toxicological assessments of agrochemical effects on stingless bees (Apidae, Meliponini). MethodsX, 100906, https://doi.org/10.1016/j.mex.2020.100906

Brandt, A., Gorenflo, A., Siede, R., Meixner, M., Büchler, R. (2016) The neonicotinoids thiacloprid, imidacloprid, and clothianidin affect the immunocompetence of honey bees (Apis mellifera L.). J. Insect Physiol., https://doi.org/10.1016/j. jinsphys.2016.01.001

Brandt, A., Grikscheit, K., Siede, R., Grosse, R., Meixner, M.D., Büchler, R. (2017) Immunosuppression in honeybee queens by the neonicotinoids thiacloprid and clothianidin. Sci. Rep., https://doi.org/10.1038 /s41598-017-04734-1

Bustin, S. A., Benes, V., Garson, J. A., Hellemans, J., Huggett, J. et al. (2009) The MIQE guidelines: minimum information for publication of quantitative realtime PCR experiments. Clin. Chem., https://doi. org/10.1373/clinchem.2008.112797.

Chaimanee, V., Evans, J.D., Chen, Y., Jackson, C., Pettis, J.S. (2016) Sperm viability and gene expression in honey bee queens (Apis mellifera) following exposure to the neonicotinoid insecticide imidacloprid and the organophosphate acaricide coumaphos. J. Insect Physiol., https://doi.org/10.1016/j.jinsphys.2016.03.004

Christen, V., Mittner, F., Fent, K. (2016) Molecular effects of neonicotinoids in honey bees (Apis mellifera). Environ. Sci. Technol., https://doi.org/10.1021/acs.est.6 b00678

Christen, V., Krebs, J., Bünter, I., Fent, K. (2019) Biopesticide spinosad induces transcriptional alterations in genes associated with energy production in honey bees (Apis mellifera) at sublethal concentrations. J. Hazard. Mater., https://doi.org/10.1016/j.jhazmat.2019.06.013.

Collison, E.J., Hird, H., Tyler, C.R., Cresswell, J.E. (2018) Effects of neonicotinoid exposure on molecular and physiological indicators of honey bee immunocompetence. Apidologie, https://doi.org/10.1007/s13592017-0541-3

Crawley, M.J. (2012). The R book. Wiley. Chichester

Cruz, D.O., Freitas, B.M., Silva, L.A., Silva, E.M.S., Bomfim, I.G.A. (2005) Pollination efficiency of the stingless bee Melipona subnitida on greenhouse sweet pepper. Pesqui. Agropecu. Bras., DOI:https://doi. org/10.1590/S0100-204X2005001200006

Dallacqua, R.P., Simões, Z.L.P., Bitondi, M.M.G. (2007) Vitellogenin gene expression in stingless bee workers differing in egg-laying behavior. Insectes Soc., https://doi.org/10.1007/s00040-007-0913-1

Del Sarto, M.C.L., Peruquetti, R.C., Campos, L.A.O. (2005). Evaluation of the Neotropical stingless bee Melipona quadrifasciata (Hymenoptera: Apidae) as pollinator of greenhouse tomatoes. J. Econ. Entomol., DOI:https://doi.org/10.1093/jee/98.2.260

Derecka, K., Blythe, M.J., Malla, S., Genereux, D.P., Guffanti, A. et al. (2013) Transient exposure to low levels of insecticide affects metabolic networks of honeybee larvae. PLoS One, https://doi.org/10.1371 /journal.pone.0068191

Desneux, N., Decourtye, A., Delpuech, J.M. (2007) The sublethal effects of pesticides on beneficial arthropods. Annu. Rev. Entomol., https://doi.org/10.1146 /annurev.ento.52.110405.091440

Disale, C.S., Dubal, R.S., Disale, S.D. (2013) Effect of some insecticides on haemocytes of japanese beetle. Online Int. Interdiscip. Res. J. 3 (2), 40-42.

Di Prisco, G., Cavaliere, V., Annoscia, D., Varricchio, P., Caprio, E., Nazzi, F., Gargiulob, G., Pennacchio, F. (2013). Neonicotinoid clothianidin adversely affects insect immunity and promotes replication of a viral pathogen in honey bees. Proc. Natl. Acad. Sci. U.S.A., https://doi.org/10.1073/pnas.1314923110

Dos Santos, S.A., Roselino, A.C., Hrncir, M., Bego, L.R. (2009) Pollination of tomatoes by the stingless bee Melipona quadrifasciata and the honey bee Apis mellifera (Hymenoptera, Apidae). Genet. Mol. Res., https://doi.org/10.4238/vol8-2kerr015

Evans, J.D., Aronstein, K., Chen, Y.P., Hetru, C., Imler, J.L.L., Jiang, H., Kanost, M., Thompson, G.J., Zou, Z., Hultmark, D. (2006) Immune pathways and defence 
mechanisms in honey bees Apis mellifera . Insect Mol. Biol., https://doi.org/10.1111/j.13652583.2006.00682.x

Garrido, P.M., Porrini, M.P., Antúnez, K., Branchiccela, B., Martínez-Noël, G.M.A., Zunino, P., Salerno, G., Eguaras, M.J., Ieno, E. (2016) Sublethal effects of acaricides and Nosema ceranae infection on immune related gene expression in honeybees. Vet. Res., https://oi.org/10.1186/s13567-016-0335-Z

Glavinic, U., Tesovnik, T., Stevanovic, J., Zorc, M., Cizelj, I., Stanimirovic, Z., Narat, M. (2019) Response of adult honey bees treated in larval stage with prochloraz to infection with Nosema ceranae. PeerJ, https://doi. org/10.7717/peerj.6325

Guedes, R.N.C., Smagghe, G., Stark, J.D., Desneux, N. (2016) Pesticide-induced stress in arthropod Pests for optimized integrated pest management programs. Annu. Rev. Entomol., https://doi.org/10.1146 /annurev-ento-010715-023646

Gullan, P.J., Cranston, P.S. (2012) Os insetos: um resumo de entomologia, Rocca, São Paulo.

Hu, Y.T., Wu, T.C., Yang, E.C., Wu, P.C., Lin, P.T., Wu, Y.L. (2017) Regulation of genes related to immune signaling and detoxification in Apis mellifera by an inhibitor of histone deacetylation. Sci. Rep., https://doi.org/10.1038/srep41255

Koch, H., Weisser, P. (1997) Exposure of honey bees during pesticide application under field conditions. Apidologie, https://doi.org/10.1051/apido:19970610

Krupke, C.H., Hunt, G.J., Eitzer, B.D., Andino, G., Given, K. (2012) Multiple routes of pesticide exposure for honey bees living near agricultural fields. PLoS One, https://doi.org/10.1371/journal.pone.0029268

Lima, M.A.P., Martins, G.F., Oliveira, E.E., Guedes, R.N.C. (2016) Agrochemical-induced stress in stingless bees: peculiarities, underlying basis, and challenges. J. Comp. Physiol. A Neuroethol. Sensory, Neural, Behav. Physiol., https://doi.org/10.1007 /s00359-016-1110-3

Lourenço, A.P., Mackert, A., Cristino, A.S., Simões, Z.L.P. (2008) Validation of reference genes for gene expression studies in the honey bee, Apis mellifera, by quantitative real-time RT-PCR*. Apidologie, https://doi. org/10.1051/apido

Lourenço, A.P., Martins, J.R., Bitondi, M.M.G., Simões, Z.L.P. (2009) Trade-off between immune stimulation and expression of storage protein genes. Arch. Insect Biochem. Physiol., https://doi.org/10.1002/arch.20301

Lourenço, A.P., Guidugli-Lazzarini, K.R., Freitas, F.C.P., Bitondi, M.M.G., Simões, Z.L.P. (2013) Bacterial infection activates the immune system response and dysregulates microRNA expression in honey bees. Insect Biochem. Mol. Biol., https://doi.org/10.1016/j. ibmb.2013.03.001

Michener, C.D. (2013) The meliponini, in: Vit, P., Pedro, S.R., Roubik, D. (Eds.), Pot-Honey: a legacy of stingless bees, Springer Science \& Business Media, New York,pp. 3-17., https://doi.org/10.1007/978-1-46144960-7_1
Nathan, S. S., Young Choi, M., Yul Seo, H., Hoon Paik, C., Kalaivani, K., Duk Kim, J. (2008) Effect of azadirachtin on acetylcholinesterase (AChE) activity and histology of the brown planthopper Nilaparvata lugens (Stål). Ecotoxicol. Environ. Saf., https://doi. org/10.1016/j.ecoenv.2007.07.005

Nunes-Silva, P., Hrncir, M., Silva, C.I., Roldão, Y.S., Imperatriz-Fonseca, V.L. (2013) Stingless bees, Melipona fasciculata, as efficient pollinators of eggplant (Solanum melongena) in greenhouses. Apidologie, https://doi.org/10.1007/s13592-0130204-y

Perveen, N., Ahmad, M., (2017) Toxicity of some insecticides to the haemocytes of giant honeybee, Apis dorsata F. under laboratory conditions. Saudi J. Biol. Sci., https://doi.org/10.1016/j.sjbs.2016.12.011

Potts, S.G., Biesmeijer, J.C., Kremen, C., Neumann, P., Schweiger, O., Kunin, W. E. (2010) Global pollinator declines: trends, impacts and drivers. Trends Ecol Evol. , https://doi.org/10.1016/j.tree.2010.01.007

Quintana, S., Bradesco, C., Negril, P., Marin, M., Pagnuco, I., Szawarski, N., Reynaldi, F., Larsen, A., Eguaras, M., Maggi, M. (2019) Up-regulated pathways in response to Deformed Wing Virus infection in Apis mellifera (Hymenoptera: Apidae). Rev. Soc. Entomol. Arg, https://doi.org/10.25085/rsea.780101

Ravaiano, S.V., Barbosa, W.F., Campos, L.A., Martins, G.F. (2018a) Variations in circulating hemocytes are affected by age and caste in the stingless bee Melipona quadrifasciata. Sci. Nat., https://doi.org/10.1007 /s00114-018-1573-X

Ravaiano, S.V., Barbosa, W.F., Tomé, H.V.V., de Oliveira Campos, L.A., Martins, G.F. (2018b) Acute and oral exposure to imidacloprid does not affect the number of circulating hemocytes in the stingless bee Melipona quadrifasciata post immune challenge. Pest. Biochem. Physiol., https://doi.org/10.1016/j. pestbp.2018.08.002

Rolff, J., Siva-Jothy, M.T. (2002) Copulation corrupts immunity: a mechanism for a cost of mating in insects. Proc. Natl. Acad. Sci., https://doi.org/10.1073 /pnas.152271999

Rortais, A., Arnold, G., Halm, M.-P., Touffet-Briens, F. (2005) Modes of honeybees exposure to systemic insecticides: estimated amounts of contaminated pollen and nectar consumed by different categories of bees. Apidologie, https://doi.org/10.1051/apido:2004071

Salgado, V.L. (1998) Studies on the mode of action of spinosad: Insect symptoms and physiological correlates. Pestic. Biochem. Physiol., https://doi. org/10.1006/pest.1998.2332

Salmela, H., Amdam, G. V., Freitak, D. (2015) Transfer of immunity from mother to offspring is mediated via egg-yolk protein vitellogenin. PLoS Pathog., https://doi.org/10.1371/journal.ppat.1005015

SAS Institute Inc. (2008). SAS/STAT® 9.2 User's Guide. Cary, NC: SAS Institute Inc

Seehuus, S.-C., Norberg, K., Gimsa, U., Krekling, T., Amdam, G. V. (2006) Reproductive protein protects functionally sterile honey bee workers from oxidative 
stress. Proc. Natl. Acad. Sci., https://doi.org/10.1073 /pnas.0502681103

Simmons, W.R., Angelini, D.R. (2017) Chronic exposure to a neonicotinoid increases expression of antimicrobial peptide genes in the bumblebee Bombus impatiens. Sci. Rep., https://doi.org/10.1038/srep44773

Silveira, F.A., Melo, G.A.R., Almeida, E.A.B. (2002) Abelhas brasileiras: sistemática e identificação. 1 edn. Belo Horizonte: Fernando Araújo Silveira.

Slaa, E., Sánchez Chaves, L., Malagodi-Braga, K., Hofstede, F. (2006) Stingless bees in applied pollination: practice and perspectives. Apidologie, https://doi. org/10.1051/apido:2006022

Strand, M.R. (2008) The insect cellular immune response. Insect Sci., https://doi.org/10.1111/j.17447917.2008.00183.x

Teles, A., Mello, T., Barchuk, A., Simões, Z. (2007) Ultraspiracle of the stingless bees Melipona scutellaris and Scaptotrigona depilis: cDNA sequence and expression profiles during pupal development. Apidologie, https://doi.org/10.1051/Apido:2007035
Tomé, H.V.V., Martins, G.F., Lima, M.A.P., Campos, L.A.O., Guedes, R.N.C. (2012) Imidacloprid-induced impairment of mushroom bodies and behavior of the native stingless bee Melipona quadrifasciata anthidioides . PLoS One, https://doi.org/10.1371/journal.pone.0038406

Tomé, H.V.V., Barbosa, W.F., Martins, G.F., Guedes, R.N.C. (2015) Spinosad in the native stingless bee Melipona quadrifasciata : Regrettable non-target toxicity of a bioinsecticide. Chemosphere, https://doi. org/10.1016/j.chemosphere.2014.11.038

Vázquez, D. E., Ilina, N., Pagano, E. A., Zavala, J. A., Farina, W. M. (2018) Glyphosate affects the larval development of honey bees depending on the susceptibility of colonies. PloS One, https://doi.org/10.1371 /journal.pone.0205074

Publisher's note Springer Nature remains neutral with regard to jurisdictional claims in published maps and institutional affiliations. 